\title{
Cytomegalovirus Virus Reactivation
}

National Cancer Institute

\section{Source}

National Cancer Institute. Cytomegalovirus Virus Reactivation. NCI Thesaurus. Code C160246.

The switching of latent cytomegalovirus to a lytic infection. 